\title{
Evolution of humoral immunity effectors in four flocks of sheep with symptoms of contagious ecthyma, from Santău village, Romania
}

\author{
ELISABETA-RAFILA MESTESANU ${ }^{1}$
}

\author{
${ }^{1}$ University of Agricultural Sciences and Veterinary Medicine Cluj-Napoca, Faculty of \\ Veterinary Medicine, Cluj-Napoca, Romania
}

\begin{abstract}
Contagious ecthyma or contagious pustular dermatitis is a debilitating condition located on the skin of sheep and goats, with a zoonotic character. Contagious ecthyma is a disease with economic and animal welfare implications, rarely being fatal if the host organism suffers from immunosuppression or if secondary infections occur. Similar to other members of the Poxviridae family, immunity to contagious ecthyma is mediated by both innate and adaptive immune responses. Following the invasion of the contagious ecthyma virus, immunoglobulins are mobilized that specifically bind to the contagious ecthyma virus to form immune complexes, which are then eliminated by defense system to protect tissues from damage. The level of circulating immune complexes and immunoglobulins can be quantified and can be an indicator of the stage of infection. In the present study we aimed to investigate whether there is a link between the individual characteristics (sex, age, severity of clinical signs) of sheep with orf symptoms and the evolution of circulating immune complexes and total immunoglobulins. In addition to these investigations, we aimed to follow the evolution of these immunological parameters compared to the evolution in clinically healthy animals. Investigations of the serum revealed that levels of these two parameters (total Ig and CIC), can be influenced by the individual characteristics of sheep affected by the contagious ectima and shows differences compared to clinically healthy animals.
\end{abstract}

Keywords Orf, ecthyma, circulating immune complexes, immunoglobulins, statistics.

To cite this article: MESTESANU ER. Evolution of humoral immunity effectors in four flocks of sheep with symptoms of contagious ecthyma, from Santău village, Romania. Rom Biotechnol Lett. 2021; 26(2): 2361-2369. DOI: 10.25083/rbl/26.2/2361.2369 


\section{Introduction}

Contagious ecthyma or contagious pustular dermatitis is a debilitating condition located on the skin of sheep and goats, with a zoonotic character (DE WET \& al [13]). It is caused by the orf virus, a Parapoxvirus (PPV), from the Chordopoxvirus subfamily (HAIG \& al [4]). Other parapoxviruses are pseudocowpoxvirus and bovine papular stomatitis virus (BPSV), which causes benign skin lesions in cattle. Viruses similar to the three members of the parapoxviruses caused infections in camels, red squirrels, seals and reindeer. Parapoxviruses have host specificity, although they can infect humans (PAL \& al [17]). Contagious ecthyma is a disease with economic and animal welfare implications, rarely being fatal if the host organism suffers from immunosuppression or if secondary infections occur (NADEEM \& al [14]). Contagious ecthyma is widespread worldwide, mainly affecting lambs and kids causing damage on the mouth and nostrils. Skin lesions progress from erythema to blisters and pustules and then form crusts that fall and are sources of infection (FLEMING \& al [18]). The virus is located in the epithelium and does not have a systemic spread. Mild lesions usually resolve within 2 weeks, and complicated lesions will resolve about one month after infection (HAIG \& al [4]). Although the evolution is generally acute, chronic, persistent infections have also been reported. $\mathrm{CD} 4^{+} \mathrm{T}$ cells, $\mathrm{CD} 8^{+} \mathrm{T}$ cells and IFN- $\gamma$ are important components of host immunity. However, the situation is complicated by the presence of immuno-modulatory virulence factors that can disrupt the host's defense mechanisms, the virus gaining time for replication (HAIG \& al [16]). The study of virulence factors of contagious ecthyma virus provides information on the pathogenesis of the virus and identifies important elements of host immunity thus highlighting the mechanism of skin response to the action of an epitheliotropic virus (BALA \& al [6]). Similar to other members of the Poxviridae family, immunity to contagious ecthyma is mediated by both innate and adaptive immune responses. Neutralizing antibodies usually occur at the end of the first week of infection, which persists for years, and their level is enhanced by revaccination. IgM antibodies were detected in animals that were recently infected. Hemagglutining antibodies appear shortly after contact with the antigen, then gradually decrease after a few years. Cell-mediated immunity is of particular importance in parapoxvirus infections (HAIG \& al [15]). Following the invasion of the contagious ecthyma virus, immunoglobulins are mobilized that specifically bind to the contagious ecthyma virus to form immune complexes, which are then eliminated by defense system to protect tissues from damage (WANG \& al [7]). The level of circulating immune complexes and immunoglobulins can be quantified and can be an indicator of the stage of infection. The detection of circulating immune complexes and immunoglobulins is not a diagnostic method, the diagnostic method dedicated to detecting contagious ecthyma virus is the polymerase chain reaction (INOSHIMA \& al [12]). The polymerase chain reaction is a method by which, with the help of primers, scientists can syntethise enzymatically viral DNA chains (DAMON $\&$ al [11]).

The purpose of this article is to study and compare the evolution of total immunoglobulins and circulating immune complexes in four flocks of sheep and in a control group. Meanwhile, we aimed to investigate whether there is a correlation between sex, age and severity of the lesions and the level of the two immunological parameters, total immunoglobulins and circulating immune complexes.

\section{Materials and Methods}

To determine the total CIC and IG, blood samples were collected from sheep from four different herds in the vicinity of the village Santău in Satu Mare county. Samples were collected in sterile tubes and then left at room temperature to express the serum. 48 samples were collected from animals with clinical signs and 18 samples from animals that showed no signs of disease, considered a control group. Samples have been divided according to the herds from which they were collected, herd no.1, a number of 22 samples, herd no.2, a number of 16 samples, herd no. 3 a number of 5 samples, herd no. 4 a number of 5 samples. For the severity of the injuries we used lesion scores from 1 to 3:1-light signs, 2-moderate signs, 3-severe signs. To reveal the correlation between sex and immunological parameters, we also used scores 1 for males and 2 for females.

\section{Dosing of the total immunoglobulins}

For the determination we used the precipitation test with Serb reagent (zinc sulfate). This dysproteinemia (or colloidal lability) test is based on the fact that at $\mathrm{pH}=7.4$ the electrical charge and colloidal stability of gammaglobulins is lower than that of serum albumin. After this diluting the serum with distilled water and adding small amounts of protein precipitating agents will result a flocculation. Flocculation is more intense as the albumin/globulin ratio is lower.

The test was performed in the "micro" version, in cell culture plates containing 96 cells, having a flat bottom. By using these plates the quantities of reactives are reduced, $196.6 \mu 1$ of Serb reagent and $3.3 \mu 1$ of serum each. Results reading was performed using the Sumal PE 2 spectrophotometer. Reading of the result was performed at a wavelength of $475 \mathrm{~nm}$ after resting plates 30 minutes at room temperature. The results obtained were expressed in Vernes degrees, obtained by multiplying by 100 the units of optical density read by the spectrophotometer. Vernes degrees representing the unit of measure of the concentration of total immunoglobulins, in the serum.

\section{Dosing of the circulating immune complexes}

Due to their large size, circulating immune complexes (CIC) can be precipitated using high molecular weight polymers, such as polyethylene glycol (PEG), even when small concentrations are present in the blood. Haskova \& al. [19]. For the determination has been used de micromethod. $6.6 \mu \mathrm{l}$ of serum, $193.4 \mu \mathrm{l}$ of borate buffer and polyethylene glycol solution were added directly into the 
cells of the flat bottom plate. Then, we performed stirring for a good homogenization of the reagents. The precipitation time is 60 minutes at room temperature. After the contact time expired, the plate was inserted into the spectrophotometer, reading the optical densities for each cell. The reading was performed using the SUMAL PE2 spectrophotometer, and compared to the buffer solution at a wavelength of $450 \mathrm{~nm}$. CIC concentrations were calculated by the difference between values of the sample treated with PEG and the sample treated with borate buffer.

\section{$C I C(U)=($ read value of the precipitaion with $P E G-$ value of the precipitation with borate buffer) $\times 1000$}

\section{Statistical analysis and validation}

For statistical analysis has been used the GraphPad Prism 8.4 program. Statistics performed in Graphpad Prism were, Pearson's correlation, one-way Anova, $t$-test and descriptive statistics (mean, standard deviation, standard error, confidence intervals).

\section{Results and Discussion}

Circulating immune complexes are aggregates that appear after antigen binding, represented by the orf virus to the corresponding antibody (MARK \& al [3]). Normally, after a short time the amount of circulating immune complexes decreases in the blood being eliminated from the body (EZEANI \& al [1]).

The control herd is the herd from which 18 samples were collected from sheep without disease signs. As reference values for total gammaglobulins and circulating immune complexes, we used the values obtained from this herd.

Table 1. Descriptive statistics and correlation for the control heard

\begin{tabular}{|c|c|c|c|}
\hline \multirow{4}{*}{$\begin{array}{c}\text { Descriptive } \\
\text { statistics }\end{array}$} & Parameters & CIC & Total Ig \\
\hline & Minimum & 0 & 6.9 \\
\cline { 2 - 4 } & Maximum & 34 & 23.2 \\
\cline { 2 - 4 } & Mean & 13.61 & 14.63 \\
\cline { 2 - 4 } & Standar deviation & 12.23 & 4.905 \\
\cline { 2 - 4 } & Standard error & 2.882 & 1.156 \\
\cline { 2 - 4 } & Confidence interval lower & 7.53 & 12.19 \\
\cline { 2 - 4 } & Confidence interval higher & 19.69 & 17.07 \\
\cline { 2 - 4 } & Coefficient of variability & $89.84 \%$ & $33.52 \%$ \\
\hline
\end{tabular}

The control herd was considered in our case, the standard, for the tests for determining the total Ig and CIC performed in the 4 herds with clinical signs (Table 1). The control herd was a group of sheep in which there were no animals with clinical signs at the time of blood collection.

The values of the correlation coefficient between the values of circulating immune complexes and total immunoglobulins returned a result indicating a poor correlation between these parameters (Table 2). The exception was herd no.1 where there was no correlation between the two parameters. Values did not met the conditions of statistical significance, so we cannot generalize for the entire population from which the samples were collected.

Table 2. Correlation between CIC and Ig values, in the herds

\begin{tabular}{|c|c|c|c|c|c|}
\hline $\begin{array}{c}\text { Correlation } \\
\text { parameters }\end{array}$ & $\begin{array}{c}\text { Correlation } \\
\text { CIC-Ig herd } \\
\text { no.1 }\end{array}$ & $\begin{array}{c}\text { Correlation } \\
\text { CIC-Ig herd } \\
\text { no.2 }\end{array}$ & $\begin{array}{c}\text { Correlation } \\
\text { CIC-Ig herd } \\
\text { no.3 }\end{array}$ & $\begin{array}{c}\text { Correlation } \\
\text { CIC-Ig her } \\
\text { no.4 }\end{array}$ & $\begin{array}{c}\text { Correlation } \\
\text { CIC-Ig control } \\
\text { herd }\end{array}$ \\
\hline$r$ & -0.09979 & 0.4142 & 0.2969 & 0.4884 & 0.3809 \\
\hline Confidence interval 95\% & -0.5003 to 0.3360 & -0.1026 to 0.7549 & -0.7931 to 0.9344 & -0.6921 to 0.9579 & -0.1046 to 0.7197 \\
\hline$r^{2}$ & 0.009959 & 0.1715 & 0.08816 & 0.2385 & 0.1451 \\
\hline$P$ & 0.6586 & 0.1107 & 0.6276 & 0.4038 & 0.1189 \\
\hline $\begin{array}{c}\text { Significant? } \\
\text { (alpha =0.05) }\end{array}$ & No & No & No & No \\
\hline
\end{tabular}

\section{Results herd no.1}

The CIC values obtained in herd no. 1 were between 0 and 47 , the mean of the values being $17.86 \pm 15.93$ which means a high dispersion compared to the mean of the herd, with a coefficient of variability of $89.15 \%$, highlighting the lack of homogenity of the batch (Table 3 ). Confidence intervals were situated between 10.8 and 24.92 at a probability of $95 \%$.

Table 3. Descriptive statistics in herd no.1

\begin{tabular}{|c|c|c|c|c|}
\hline \multirow{4}{*}{$\begin{array}{c}\text { Descriptive } \\
\text { statistics herd no.1 }\end{array}$} & Parameters & CIC herd & Ig herd & Age \\
\cline { 2 - 5 } & Mean & 17.86 & 13.12 & 17 \\
\cline { 2 - 5 } & Standard deviation & 15.93 & 5.734 & 17.85 \\
\cline { 2 - 5 } & Standard error & 3.395 & 1.222 & 3.806 \\
\cline { 2 - 5 } & Lower confidecce & 10.8 & 10.58 & 9.085 \\
\cline { 2 - 5 } & Higher confidence & 24.92 & 15.66 & 24.91 \\
\cline { 2 - 5 } & Coefficient of & $89.15 \%$ & $43.70 \%$ & 105.0 \\
\hline
\end{tabular}

The mean age of the group was $17 \pm 17.85$ months, with values between 3 and 48 months. An attempt was made to establish the existence of a correlation between the values obtained when dosing the circulating immune complexes and the age of the sheep. The value 0.2 obtained by calculating the Pearsons correlation coefficient revealed that there is a very small correlation between the age of sheep in herd no.1 and CIC values. The majority of the affected sheep from herd no. 1 were females $(68.18 \%)$. The correlation between sex and CIC level revealed a weak correlation between sex and CIC level in the sense of a slight increase in CIC values in males. Regarding the severity of the lesions, no link was found between them and the level of circulating immune complexes. When testing total immunoglobulins, in herd no.1 the values were between 0.04 and 24 , the mean values being $13.12 \pm 5.73$ with a coefficient of variability of $43.70 \%$ which indicates 
a high variability of data of the specimens taken into account. The confidence intervals at a significance of 95\% were between 10.58 and 15.66 (Table 4). As in case of circulating immune complexes, a weak correlation was observed between the sex of the animals and the result obtained at total Ig dosing, which indicates a slight tendency to increase of Ig values in males. In case of correlation of the severity of the lesions with the total Ig values, it was observed that there is no connection between the severity of the lesions and the total Ig. Correlation between Ig and CIC level detected in herd no.1 was not highlighted, the value of the correlation index had a tendency to reach value 0 , which means that there is no causal link between Ig and CIC value.

Table 4. Pearsons correlation values in herd no.1

\begin{tabular}{|c|c|c|c|c|c|c|c|}
\hline Parameters & $\begin{array}{c}\text { Sex } \\
\text { vs CIC }\end{array}$ & $\begin{array}{c}\text { Age } \\
\text { vs CIC }\end{array}$ & $\begin{array}{c}\text { Lesions } \\
\text { vs CIC }\end{array}$ & $\begin{array}{c}\text { CIC } \\
\text { vs Ig }\end{array}$ & $\begin{array}{c}\text { Sex } \\
\text { vs Ig }\end{array}$ & $\begin{array}{c}\text { Age } \\
\text { vs Ig }\end{array}$ & $\begin{array}{c}\text { Lesions } \\
\text { vs Ig }\end{array}$ \\
\hline Pearson correlation $(\mathrm{R})$ & -0.2569 & 0.2074 & -0.06028 & 0.3809 & 0.2351 & -0.03342 & -0.136 \\
\hline $\begin{array}{c}\text { Confidence interval } \\
(95 \%)\end{array}$ & $\begin{array}{c}-0.6122 \text { to } \\
0.1848\end{array}$ & $\begin{array}{c}-0.2348 \text { to } \\
0.5784\end{array}$ & $\begin{array}{c}-0.4699 \text { to } \\
0.3707\end{array}$ & $\begin{array}{c}-0.1046 \text { to } \\
0.7197\end{array}$ & $\begin{array}{c}-0.2070 \text { to } \\
0.5975\end{array}$ & $\begin{array}{c}-0.4487 \text { to } \\
0.3937\end{array}$ & $\begin{array}{c}-0.5274 \text { to } \\
0.3030\end{array}$ \\
\hline $\mathrm{R}^{2}$ & 0.06598 & 0.043 & 0.003634 & 0.1451 & 0.0553 & 0.001117 & 0.0185 \\
\hline $\mathrm{P}$ & 0.2485 & 0.3545 & 0.7899 & 0.1189 & 0.2921 & 0.8826 & 0.5462 \\
\hline Significant? $(\alpha=0.05)$ & no & no & no & no & no & no & no \\
\hline
\end{tabular}

To compare values obtained in herd no. 1 with control herd, which includes clinically healthy animals. So the values of circulating complexes were between 0 and 34 units, the mean being $13.61 \pm 12.23$, the coefficient of variation being high $89.84 \%$ with confidence limits between 7.53 and 19.69, indicating a high degree of variability of values. The total Ig was between 6.90 and 23.20 , with an mean of $14.63 \pm 4.90$ with a slightly lower coefficient of variation $33.51 \%$, with confidence limits between 10.58 and 15.6. In order to see the differences between the immunological constants obtained between herd no. 1 and the control herd, we used the $t$ test. The result showed that at a confidence of $95 \%$, there are no differences between herd no.1 and control herd. The same result was obtained in case of total Ig (Table 5).

Table 5. T-test between herd no.1 and control herd

\begin{tabular}{|c|c|c|}
\hline T-test parameters & CIC herd no.1 vs CIC control herd & Ig herd no.1 vs Ig control herd \\
\hline P values & 0.3583 & 0.3816 \\
\hline Significat? $(\mathrm{p}<0.05) ?$ & no & no \\
\hline$t$ & $t=0.9298$ & $t=0.8852$ \\
\hline Difference between means \pm ES & $-4.253 \pm 4.573$ & $1.513 \pm 1.709$ \\
\hline Confidence interval (95\%) & -13.51 to 5.006 & -1.947 to 4.974 \\
\hline F (to compare variances) & 1.696 & 1.367 \\
\hline $\mathrm{p}$ & 0.2725 & 0.5177 \\
\hline Significant $(\mathrm{p}<0.05) ?$ & no & no \\
\hline
\end{tabular}

\section{Results herd no.2}

In herd no.2, a number of 16 samples were included, with sheep aged between 4 and 120 months, with a mean of $28.25 \pm 44.05$ months, the coefficient of variation for age was $155,9 \%$, which means that animals with great age differences were included in the analysis group (Table 6). The CIC values were between 0 and 44 units with an mean of $17.94 \pm 13.94$ units, a coefficient of variation of $77.72 \%$, which indicates that even in this case the values are not homogeneous concentrated around a medium but intensely dispersed, the ranges of the mean being between 10.51 and 25.37 Vernes degrees, at a confidence level of 95\%. Total immunoglobulins have recorded values between 10.9 and 24 with an mean of $14.31 \pm 3.8$ units, the coefficient of variation was significantly lower than in circulating immune complexes $(26.63 \%)$, the confidence interval of the mean being between 12.28 and 16.34 at a probability of $95 \%$.
Table 6. Descriptive statistics herd no.2

\begin{tabular}{|c|c|c|c|c|}
\hline \multirow{4}{*}{$\begin{array}{c}\text { Descriptive } \\
\text { statistics }\end{array}$} & Parameters & CIC & Ig & Age \\
\cline { 2 - 5 } & Mean & 17.94 & 14.31 & 28.25 \\
\cline { 2 - 5 } & Standard deviation & 13.94 & 3.809 & 44.05 \\
\cline { 2 - 5 } & $\begin{array}{c}\text { Lower confidence } \\
\text { value (95\%) }\end{array}$ & 10.51 & 12.28 & 4.775 \\
\cline { 2 - 5 } & $\begin{array}{c}\text { Higher confidence } \\
\text { value (95\%) }\end{array}$ & 25.37 & 16.34 & 51.72 \\
\cline { 2 - 5 } & $\begin{array}{c}\text { Coefficient of } \\
\text { variation }\end{array}$ & $77.72 \%$ & $26.63 \%$ & $155.9 \%$ \\
\hline
\end{tabular}

When correlating sex with the values of circulating immune complexes, the value obtained was very close to 0 , which means that there is no connection between the sex of animals and the evolution of the CIC level. The correlation index between the age of the animals and the CIC level was calculated, the existence of a correlation between age and the CIC level was not observed, the value being close to 0 , 
which means that the 2 values evolve independently of each other. The same result was obtained when calculating the correlation between lesion scores and CIC. There is no correlation between sex and total Ig level, but a weak positive correlation was calculated between the age of the affected sheep and the Ig level in the case of herd no.2, the evolution of total Ig showing a slight evolution according to age (Table 7). A medium correlation has been observed between Ig and lesion severity. The more serious lesions have been observed the lower the ig levels were.

Table 7. Correlations in herd no.2

\begin{tabular}{|c|c|c|c|c|c|c|c|}
\hline $\begin{array}{c}\text { Correlation } \\
\text { parameters }\end{array}$ & $\begin{array}{c}\text { Sex } \\
\text { vs CIC }\end{array}$ & $\begin{array}{c}\text { Age } \\
\text { vs CIC }\end{array}$ & $\begin{array}{c}\text { Lesions } \\
\text { vs CIC }\end{array}$ & $\begin{array}{c}\text { CIC } \\
\text { vs Ig }\end{array}$ & $\begin{array}{c}\text { Sex } \\
\text { vs Ig }\end{array}$ & $\begin{array}{c}\text { Age } \\
\text { vs Ig }\end{array}$ & $\begin{array}{c}\text { Lesions } \\
\text { vs Ig }\end{array}$ \\
\hline $\mathrm{r}$ & 0.1045 & 0.08025 & 0.0712 & 0.4142 & -0.007869 & 0.2609 & -0.4184 \\
\hline $\begin{array}{c}95 \% \text { confidence } \\
\text { interval }\end{array}$ & -0.4125 to & $\begin{array}{c}-0.4327 \text { to } \\
0.5707\end{array}$ & $\begin{array}{c}-0.4400 \text { to } \\
0.5476\end{array}$ & $\begin{array}{c}-0.1026 \text { to } \\
0.7549\end{array}$ & $\begin{array}{c}-0.5016 \text { to } \\
0.4897\end{array}$ & $\begin{array}{c}-0.2697 \text { to } \\
0.6700\end{array}$ & $\begin{array}{c}-0.7571 \text { to } \\
0.09749\end{array}$ \\
\hline$p$ & 0.7 & 0.7677 & 0.7933 & 0.1107 & 0.9769 & 0.3291 & 0.1067 \\
\hline $\begin{array}{c}\text { Significant? } \\
(\alpha=0.05)\end{array}$ & no & no & no & no & no & no \\
\hline
\end{tabular}

Between measured values of CIC and total Ig, in herd no.2, was revealed the existence of a weak positive correlation, the total Ig values having a slight tendency to increase with the increase of CIC. The differences between herd no. 2 and control herd were insignificant in terms of total Ig and CIC values. According to this, we performed the $t$ test at a confidence level of $95 \%$, the differences between the mean values of CIC and total Ig being $-0.32 \pm 1.52$ showed in Table 8 .

Table 8. T-test between herd no. 2 and control herd

\begin{tabular}{|c|c|c|}
\hline T test parameters & CIC herd no.2 vs. CIC control herd & Ig herd no.2 vs. Ig control herd \\
\hline $\mathrm{p}$ & 0.3422 & 0.831 \\
\hline Significant? $(\mathrm{P}<0.05)$ ? & no & no \\
\hline$t$ & $t=0.9642$ & 0.2151 \\
\hline Difference between means $\pm \mathrm{ES}$ & $4.326 \pm 4.487$ & -2.770 to 3.424 \\
\hline Confidence interval 95\% & -4.813 to 13.47 & 1.658 \\
\hline F, to compare variances & 1.299 & 0.3308 \\
\hline $\mathrm{P}$ & 0.5989 & no \\
\hline Significant $(\mathrm{P}<0.05) ?$ & no & \\
\hline
\end{tabular}

\section{Results herd no.3}

From herd no. 3 five samples were collected from animals aged between 4 and 5 months, the average age being $4.2 \pm 0.44$ months. The CIC value was between 4 and 30 , with an average of $19.40 \pm 6.58$ units, and a coefficient of variability of $50.85 \%$ with a confidence interval for $95 \%$ of the population between 7.15 and 31.65 (Table 9). This indicates that the values have a high dispersion and do not tend to group around the mean values. The total Ig values were between 12.50 and 26.9, the average being $19.20 \pm 6.58$, the coefficient of variability being $34.28 \%$, with a confidence interval between 11.03 and 23.37. Circulating Ig valueshad a stronger tendence to group aroun de mean.
Table 9. Descriptive statistics herd no.3

\begin{tabular}{|c|c|c|c|c|}
\hline \multirow{4}{*}{$\begin{array}{c}\text { Descriptive } \\
\text { statistics }\end{array}$} & Parameters & CIC & Ig & Age \\
\cline { 2 - 5 } & Mean & 19.4 & 19.2 & 4.2 \\
\cline { 2 - 5 } & Standard deviation & 9.864 & 6.581 & 0.4472 \\
\cline { 2 - 5 } & $\begin{array}{c}\text { Lower confidence } \\
\text { interval (95\%) }\end{array}$ & 7.152 & 11.03 & 3.645 \\
\cline { 2 - 5 } & $\begin{array}{c}\text { Higher confidence } \\
\text { interval (95\%) }\end{array}$ & 31.65 & 27.37 & 4.755 \\
\cline { 2 - 5 } & Coefficient of variation & $50.85 \%$ & $34.28 \%$ & $10.65 \%$ \\
\hline
\end{tabular}

Correlating sex with the values obtained at CIC, in the case of our samples it was found the existence of a close correlation between sex and the value of CIC, CIC having a tendency to increase in the case of males. And in the case of the age, a negative correlation was observed this time, the CIC values increasing with decreasing age. The correlation between lesion scores and CIC was intensely positive (Table 10).

Table 10. Correlations in herd no. 3

\begin{tabular}{|l|c|c|c|c|c|c|c|}
\hline \multicolumn{1}{|c|}{ Parameters } & $\begin{array}{c}\text { Sex } \\
\text { vs CIC }\end{array}$ & $\begin{array}{c}\text { Age } \\
\text { vs CIC }\end{array}$ & $\begin{array}{c}\text { Lesions } \\
\text { vs CIC }\end{array}$ & $\begin{array}{c}\text { CIC } \\
\text { vs Ig }\end{array}$ & $\begin{array}{c}\text { Sex } \\
\text { vs Ig }\end{array}$ & $\begin{array}{c}\text { Age } \\
\text { vs Ig }\end{array}$ & $\begin{array}{c}\text { Lesions } \\
\text { vs. Ig }\end{array}$ \\
\hline $\mathrm{r}$ & 0.8727 & -0.8727 & 0.09068 & 0.2969 & 0.5691 & -0.5691 & 0.6541 \\
\hline Confidence & -0.04138 to & -0.9915 to & -0.8604 to & -0.7931 to & -0.6290 to & -0.9662 to & -0.5396 to \\
interval 95\% & 0.9915 & 0.04138 & 0.9009 & 0.9344 & 0.9662 & 0.6290 & 0.9742 \\
\hline $\mathrm{R}^{2}$ & 0.7617 & 0.7617 & 0.008222 & 0.08816 & 0.3239 & 0.3239 & 0.4278 \\
\hline $\mathrm{P}$ & 0.0534 & 0.0534 & 0.8847 & 0.6276 & 0.3167 & 0.3167 & 0.2311 \\
\hline Significant? $(\alpha=0.05)$ & No & No & No & No & No & No & No \\
\hline
\end{tabular}


The correlation between the CIC and total Ig values in herd no.3 was weak, the value having no statistical significance. To compare the values obtained compared to the control herd, the $t$ test was used, both in the case of CIC and in the case of total Ig the differences were insignificant, the averages of the values being very close in our case (Table 11).

Table 11. T-test between herd no. 3 and control herd

\begin{tabular}{|c|c|c|}
\hline Parameters & $\begin{array}{c}\text { CIC herd no.3 } \\
\text { vs CIC control herd }\end{array}$ & $\begin{array}{c}\text { Ig herd no.3 } \\
\text { vs Ig control herd }\end{array}$ \\
\hline $\mathrm{P}$ & 0.3435 & 0.1009 \\
\hline Significance $(\mathrm{P}<0.05) ?$ & No & No \\
\hline$t$ & $t=0.9692$ & $t=1.716$ \\
\hline Mean difference $\pm \mathrm{ES}$ & $-5.789 \pm 5.973$ & $-4.567 \pm 2.662$ \\
\hline Confidence interval 95\% & -18.21 to 6.632 & 1.8 \\
\hline F test, to compare variances & 1.537 & 0.3506 \\
\hline $\mathrm{P}$ & 0.7316 & No \\
\hline Significant $(\mathrm{P}<0.05) ?$ & No & 0.9687 \\
\hline
\end{tabular}

\section{Results herd no.4}

In the case of herd no.4, five samples were taken from female sheep aged between 3 and 96 months, the mean age being $44.40 \pm 40.55$, the group not being homogeneous according to the age. The CIC values were between 14 and 80 units with an average of $45.60 \pm 30.97$ units, the coefficient of variability was $67.92 \%$, with a confidence interval between 7.14 and 84.06 (Table 12). The dispersion of CIC values was high, all being far from the average value. Total Ig recorded values between 7.4 and 14.30, the group average being $9.22 \pm 2.94$ units, the calculated coefficient of variability recorded the value of $31.97 \%$, with the confidence interval between 5.56 and 12.88. As with the other herds, the dispersion of total ig values was lower.

Pearsons correlation between Ig and CIC values, in herd no.4, showed the existence of a positive correlation of medium intensity. The correlation between sex and total Ig and CIC did not return any results (Table 13). The correlation between age and CIC revealed that there is no
Table 12. Descriptive statistics for herd no.4

\begin{tabular}{|c|c|c|c|c|}
\hline \multirow{7}{*}{$\begin{array}{c}\text { Descriptive } \\
\text { statistics }\end{array}$} & Parameters & $\begin{array}{c}\text { CIC herd } \\
\text { no.4 }\end{array}$ & $\begin{array}{c}\text { Ig herd } \\
\text { no.4 }\end{array}$ & Age \\
\hline & Mean & 45.6 & 9.22 & 44.4 \\
\hline & Standar deviation & 30.97 & 2.947 & 40.55 \\
\hline & Standard error & 13.85 & 1.318 & 18,13 \\
\hline & $\begin{array}{c}\text { Lower } \\
\text { confidence } 95 \%\end{array}$ & 7.142 & 5.56 & -5.949 \\
\hline & $\begin{array}{c}\text { Higher } \\
\text { confidence } 95 \%\end{array}$ & 84.06 & 12.88 & 94.75 \\
\hline & $\begin{array}{c}\text { Coefficient of } \\
\text { variation }\end{array}$ & $67.92 \%$ & $31.97 \%$ & $91.33 \%$ \\
\hline
\end{tabular}

causal link between CIC and age, but a moderate positive correlation was calculated between the lesion score and CIC. The results of the correlations cannot be applied to the group samples were collected from, because they have no statistical significance.

Table 13. Correlation in herd no.4

\begin{tabular}{|c|c|c|c|c|c|c|c|}
\hline Parameters & $\begin{array}{c}\text { Sex- } \\
\text { CIC }\end{array}$ & $\begin{array}{c}\text { Age } \\
\text { vs. CIC }\end{array}$ & $\begin{array}{c}\text { Lesions } \\
\text { vs. CIC }\end{array}$ & CIC vs. Ig & $\begin{array}{c}\text { Sex } \\
\text { vs. Ig }\end{array}$ & $\begin{array}{c}\text { Age } \\
\text { vs Ig }\end{array}$ & $\begin{array}{c}\text { Lesions } \\
\text { vs. Ig }\end{array}$ \\
\hline $\mathrm{r}$ & - & 0.1502 & 0.4156 & 0.4884 & - & -0.7523 & 0.223 \\
\hline $\begin{array}{c}\text { Confidence } \\
\text { interval 95\% }\end{array}$ & - & $\begin{array}{c}-0.8439 \text { to } \\
0.9117\end{array}$ & $\begin{array}{c}-0.7369 \text { to } \\
0.9497\end{array}$ & $\begin{array}{c}-0.6921 \text { to } \\
0.9579\end{array}$ & - & $\begin{array}{c}-0.9825 \text { to } \\
0.3865\end{array}$ & $\begin{array}{c}-0.8207 \text { to } \\
0.9236\end{array}$ \\
\hline $\mathrm{r}^{2}$ & - & 0.02257 & 0.1727 & 0.2385 & - & 0.5659 & 0.04973 \\
\hline $\mathrm{P}$ & - & 0.8094 & 0.4865 & 0.4038 & - & 0.1424 & 0.7184 \\
\hline $\begin{array}{c}\text { Significant? } \\
(\alpha=0.05)\end{array}$ & - & No & No & No & - & No & No \\
\hline
\end{tabular}

A strong negative correlation has been revealed between Ig and age and a weak correlation with lesion severity. In case of comparing the results obtained to determine the total CIC and Ig between herd no. 4 and the control herd, $t$ test was used. The result for both CIC and Ig was that there is a weak relation between the 2 sets of values at a significance level of 95\% (Table 14). Comparing CIC and Ig in herd no.4 with CIC and Ig in control herd, $t$-test showed a significant difference between the means of the two groups. 
Table 14. T-test herd no. 4 vs control herd

\begin{tabular}{|c|c|c|}
\hline Parameters & CIC herd no.4 vs. CIC control herd & Ig herd no.4 vs Ig control herd \\
\hline $\mathrm{P}$ & 0.0016 & 0.0299 \\
\hline Significant $(\mathrm{P}<0.05) ?$ & Yes & Yes \\
\hline$t$ & $t=3.6$ & $t=2.330$ \\
\hline Mean differences $\pm \mathrm{ES}$ & $-31.99 \pm 8.811$ & $5.413 \pm 2.324$ \\
\hline Confidence interval 95\% & -50.31 to -13.67 & 0.5810 to 10.25 \\
\hline F test to compare variances & 6.415 & 2.769 \\
\hline $\mathrm{P}$ & 0.0049 & 0.3344 \\
\hline Significant $(\mathrm{P}<0.05) ?$ & Yes & No \\
\hline
\end{tabular}

To compare the total CIC and Ig values obtained in the 4 herds the ANOVA test has been performed, a variant of the $t$ test, which allows the comparison of more than two data sets of the same kind. For circulating immune complexes the overall result showed that the mean CIC values are different from each other at a significance level of $95 \%$. Checking the relationship between the averages of the herds taken two by two, obtained by the method of multiple comparisons Tukey, it was found that there is a major difference between herd no.1 and herd no. 4 and herd no. 2 and herd no.4. The comparisons made between the remaining herds did not return the existence of a significant difference. The same statistical calculations were used in the case of comparing the total Ig levels between the 4 experimental herds difference was significant between herd no.4 and herd 1 and 2, but nor between herd no. 4 and 3 (Table 15).

Table 15. One way Anova and Tukey test between group means

\begin{tabular}{|c|c|c|c|c|c|c|c|c|}
\hline \multirow{3}{*}{ Anova } & \multicolumn{4}{|c|}{ CIC } & \multicolumn{4}{|c|}{ Ig } \\
\hline & $\mathrm{F}$ & $\mathrm{P}$ & $\begin{array}{c}\text { Significant } \\
\text { difference } \\
\text { between means? }\end{array}$ & $\mathrm{R}^{2}$ & F & $\mathrm{P}$ & $\begin{array}{c}\text { Significant } \\
\text { difference } \\
\text { between means? }\end{array}$ & $\overline{\mathrm{R}^{2}}$ \\
\hline & 4.005 & 0.0132 & Yes & 0.2145 & 3.48 & 0.0236 & Yes & 0.1918 \\
\hline Tukey test & Mean diff. & $\begin{array}{c}95.00 \% \\
\text { confidence } \\
\text { interval }\end{array}$ & Significant? & Adjusted P & Mean diff. & $\begin{array}{c}95 \% \\
\text { confidence } \\
\text { interval }\end{array}$ & Significant? & Adjusted P \\
\hline Herd 1 vs. Herd 2 & -0.07386 & -14.84 to 14.69 & No & $>0.9999$ & -1.186 & -5.604 to 3.232 & No & 0.8899 \\
\hline Herd 1 vs herd 3 & -1.536 & -23.80 to 20.73 & No & 0.9977 & -6.08 & -12.74 to 0.5822 & No & 0.0849 \\
\hline Herd 1 vs herd 4 & -27.74 & $\begin{array}{c}-50.00 \text { to } \\
-5.469\end{array}$ & Yes & 0.0093 & 3.9 & -2.762 to 10.56 & No & 0.4098 \\
\hline Herd 2 vs herd 3 & -1.463 & -24.49 to 21.57 & No & 0.9982 & -4.894 & -11.78 to 1.996 & No & 0.2443 \\
\hline Herd 2 vs herd 4 & -27.66 & $\begin{array}{c}-50.69 \text { to } \\
-4.635 \\
\end{array}$ & Yes & 0.0129 & 5.086 & -1.803 to 11.98 & No & 0.2144 \\
\hline Herd 3 vs herd 4 & -26.2 & -54.63 to 2.226 & No & 0.0805 & 9.98 & 1.475 to 18.48 & Yes & 0.0157 \\
\hline Tukey test details & Mean 1 & Mean 2 & Means diff. & SE of differences & Mean1 & Mean 2 & Means diff. & SE of differences \\
\hline Herd 1 vs. Herd 2 & 17.86 & 17.94 & -0.07386 & 5.531 & 13.12 & 14.31 & -1.186 & 1.655 \\
\hline Herd 1 vs herd 3 & 17.86 & 19.4 & -1.536 & 8.34 & 13.12 & 19.2 & -6.08 & 2.495 \\
\hline Herd 1 vs herd 4 & 17.86 & 45.6 & -27.74 & 8.34 & 13.12 & 9.22 & 3.9 & 2.495 \\
\hline Herd 2 vs herd 3 & 17.94 & 19.4 & -1.463 & 8.625 & 14.31 & 19.2 & -4.894 & 2.58 \\
\hline Herd 2 vs herd 4 & 17.94 & 45.6 & -27.66 & 8.625 & 14.31 & 9.22 & 5.086 & 2.58 \\
\hline Herd 3 vs herd 4 & 19.4 & 45.6 & -26.2 & 10.65 & 19.2 & 9.22 & 9.98 & 3.185 \\
\hline
\end{tabular}

There was no big difference between the CIC values when comparing the average values obtained between the 4 herds, except for the comparison of the values from herd no. 1 vs. Herd no. 4 and herd no. 2 and herd no.4, where following the Tukey test it was found the existence of significant differences. The average of herd no.4 being much higher than the average of herd 2 and herd no.1, it could be concluded that in herd no.4 the contagious ectima was at the beginning, the number of circulating immune complexes being higher. However, compared to herd no. 3 the differences were not so obviuos, the average of the herd no. 4 was in this case higher than in herd no.3. We can also conclude in this case that in herd no. 3 the disease was in a incipient phase, when relates to the other herds. The values in herds 3 and 4 showed quite large variations compared to herd no.1 and herd no.2, as evidenced by the wide confidence interval determined by performing the Tukey test. Considering that the values from herd no. 1 and herd no. 2 were close to those of the control herd we can consider the fact that the sheep from herd no. 1 and herd no.2 were in the depression phase of the level of immune complexes circulating, as well as herd no. 3 showed tendencies to 
approach as values the values determined in the control herd. The values of total immunoglobulins calculated for the 4 herds compared to each other showed a relative homogeneity, being significant differences between the comparison of total Ig between herd no. 3 and herd no.4. The total Ig values between the 4 experimental herds showed similar averages except herd no.4, which had a significantly lower average than herd no.3. In relation to the other herds, the difference in the average values from herd no. 4 were not statistically significant but they were still obvious, which may mean that there is an increased level of complexed Ig in the form of immune complexes circulating in the blood. So herd no. 4 could be in the primary phase of disease evolution. However, given the low number of samples and the large differences between the values recorded, we cannot generalize. The values of CIC from herd no. 1 , herd no. 2 and herd no. 3 were closer to the values from the control herd, almost insignificant in the case of herd no. 1 and 2, there is a possibility that the animals may be in the remission phase of the disease. The average values of the circulating immune complexes of the control herd compared to those of the experimental herds did not reveal large differences, which shows that the tendency was to keep the value of immunoglobulins constant in the body and in case of infectious aggression, we can also conclude if we follow standard deviations and confidence intervals within less extensive limits than in circulating immune complexes. The circulating immune complexes determined in the control herd, on the other hand, had lower average values than the four experimental herds, in the case of herd no. 4 difference was significant. Larger standard deviations and high confidence intervals for circulating immune complex values argue for greater variability in this parameter, in part due to the ability of immunoglobulins to complex and the ability of organisms to remove these circulating immune complexes from circulation. So we can conclude that, in case of orf infections one of the mostly variable parameters is the level of circulating immune complexes. The correlations of the two parameters, Ig and CIC, with the sex of the animals revealed in herd no. 1 and herd no. 3 a slight correlation but without statistical significance. In herd no. 4 , this type of correlation could not be performed because the samples collected were from animals with the same sex, so the test did not return any results. In the case of the same parameters correlated with the age of the animals, showed a tendency of higher levels in Ig in lambs. This can be explained either by the antibodies taken from the mother's colostrum or by the fact that the lambs do not have Ig specific for the contagious ecthyma virus (WANG \& al [7]). What should be noted is that lambs do not have maternal immunity in the case of contagious ectemia, as they are fully exposed to infection (MUSSER \& al [10]). Increased age of the subject, indicating a better ability to complex between antigen and immunoglobulins, probably due to repeated interactions with the contagious ectemia virus throughout life (KUMAR \& al [5]). An insignificant correlation existed only in the case of herd no. 1 but the trend was the same as in the case of the other three herds. Between the lesions and the two parameters, total Ig and CIC, except for herd no. 1, the rest of the herds showed a stronger correlation of increasing the number of $\mathrm{Ig}$ depending on the lesion score, the more severe the lesions were, the more the tendency of the Ig level total was to increase. CIC values showed a greater variability than Ig, variation being lower and and having a tendency to group arond mean values.

\section{Conclusions}

We can say that the levels of these two parameters (total Ig and CIC), can be influenced by the individual characteristics of sheep affected by the contagious ecthyma and vary compared to clinically healthy animals. Although evolution of orf can be influenced by sex and age of the animals, levels of CIC and total Ig are not being influenced by these charateristics or by the severity of the lesions, a possible influence being due to hazard. As literature describes levels of hemagglutining and neutralizing antibodies increase 10-12 days after disease outbreak (BALA \& al [6]), in our case we can say that higher levels of total IG can be the result of the increasing levels these tipes of antibodies. However, the fact that the sheep are clinically healthy does not exclude the fact that they have had mild evolutions of orf and have recovered without scars or are carriers of the virus. Given that the total Ig level begins to increase after a relatively long time after infection (KUMAR \& al [5]), the results obtained in this paper suggest that low levels Ig can suggest that the disease was in an early stage when antibody production has not yet started. Cases when Ig levels are closer to those of clinically healthy animals can be explained by the possibility that the sheep in the control group may have been exposed to the virus some time before and still have protective antibodies in the blood. But in the other hand, this does not exclude that ill animals can be in earlier stages of the disease, as it is known that antibody levels increase a long time after infection. Increased levels of Ig values in some cases in young animals may be due either to the fact that they they are receiving antibodies from milking mothers, but not against contagious ecthyma. Levels of CIC in orf infection as in any other disease show a higher variability than Ig, because of their short term life, levels of Ig showing a greater stability.

\section{Acknowledgements}

Funding for the publication, editing, laboratory methods has been provided from my personal funds, no public or other funds have been used. Special thanks to 
Dr. Olah Diana, for the help offerred during laboratory determinations and to Prof. Dr. Marina Spînu for guiding my whole activity.

\section{Conflicts of Interest Disclosure}

There are no conflicts of interest known in this paper. This manuscript does not contain previously published content an is not offered for publication anywhere else. All authors have read this paper and agreed the final form.

\section{Compliance with ethical standards}

The manuscript is conform with Uniform Requirements for Manuscripts Submitted to Biomedical Journals (ICMJE), and the paper has been conducted according to internationally accepted ethical standards ( $\underline{\mathrm{COPE}}$ ).

\section{Abbreviations}

CIC-circulating immune complexes

Ig-totalr immunoglobulins

r-Pearsons correlation coeficient

PEG-polyethylene glycol

\section{References}

1. M.C. EZEANI, C.C. ONYENEKWE, S.C. MELUDU. Persistent Circulating Immune Complexes: Potential Source of Epimutation and Cancer Poor Prognosis. International Journal of Genetics and Genomics. Vol. 5, No. 1, pp. 1-13 (2017).

2. W. MARK. Tests for Circulating Immune Complexes. Methods in molecular biology (Clifton, N.J.). 1134. 47-57 (2014).

3. D. HAIG. Orf virus infection and host immunity. Current opinion in infectious diseases. 19. 127-31 (2006).

4. R. KUMAR, D. TRIVEDI, P. BHATT, S. KHAN, S. KHURANA, R. TIWARI, K. KARTHIK, Y. MALIK, K. DHAMA, R. CHANDRA. Contagious Pustular Dermatitis (Orf Disease) - Epidemiology, Diagnosis, Control and Public Health Concerns. Advances in Animal and Veterinary Sciences. 3. 649-676 (2015).

5. J.A. BALA, K.N. BALAKRISHNAN, A.A. ABDULLAH, R. MOHAMED, A.W. HARON, F.F.A. JESSE, M.L. MOHD-AZMI. The re-emerging of orf virus infection: A call for surveillance, vaccination and effective control measures. Microbial Pathogenesis, 120, 55-63 (2018).
6. T. WANG, M. ZHANG, H. ZHOU, D. CUI, X. XU, C. SUN, J. CHENG. Establishment and evaluation of a general dissociation technique for antibodies in circulating immune complexes. Clinical and Experimental Medicine 19:67-75 (2018).

7. Y. DAI, Z. HU, Y. CHEN, B. LOU, D. CUI, A. XU, Y. RAO, J. HE, J. YANG, X. ZENG, X. XU, G. WANG, J. XU, T. ZHOU, C. SUN, J. CHENG. A Novel General and Efficient Technique for Dissociating Antibody in Circulating Immune Complexes. ELECTROPHORESIS. 39. 10.1002/elps.201700246. (2017).

8. J. LLOYD, D. HAIG. Scabby mouth and the ovine immune response Proceedings of the Australian Sheep Veterinairans 2004 Conference (AVA Canberra), At Canberra, Volume: 24 (2004).

9. J.M. MUSSER, C.A. TAYLOR, J. GUO, I.R. TIZARD, J.W. WALKER. Development of a contagious ecthyma vaccine for goats. Am J Vet Res., 69(10):1366-70 (2008).

10. I. DAMON. Poxviridae and their replication. In Fields Virology, Raven Press Ltd. New York: 2079-2081 (2013).

11. Y. INOSHIMA, M. TAKASU, N. ISHIGURO. Establishment of an on-site diagnostic procedure for detection of Orf virus from oral lesions of Japanese serows (Capricornis crispus) by loop-mediated isothermal amplification. J. Vet. Med. Sci. 78(12):18411845 (2016).

12. C. DE WET, J. MURIE. Lamb pays lip service: two cases of ecthyma contagiosum (orf). Scott. Med. J. 56(1):59 (2011).

13. M. NADEEM, P. CURRAN, R. COOKE, C.A. RYAN, K. CONNOLLY. Orf: contagious pustular dermatitis. Ir Med J. 103(5):152-153 (2010).

14. D.M. HAIG, C.J. MCINNES. Immunity and counterimmunity during infection with the parapoxvirus orf virus. Virus Research, 88(1-2), 3-16 (2002).

15. D.M. HAIG, J. HOPKINS, H.R.P. MILLER. Local immune responses in afferent and efferent lymph. Immunology 96, 155-163 (1999).

16. M. PAL, S. TESFAYE, P. DAVE. Zoonoses Occupationally Acquired By Abattoir Workers. J. Environ. Occu. Sci. 2(3):155-162 (2013).

17. S.B. FLEMING, L.M. WISE, A.A. MERCER. Molecular genetic analysis of orf virus: A poxvirus that has adapted to skin. Viruses 7(3), 1505-1539 (2015).

18. V. HASKOVA, J. KALIK, I. RIHA, I . MN, J. REVENSLY. Simple method of circulating complex detection in human sera by polyethylene glycolprecipitation Z. Imm. Forsch 154; 399-405 (1978). 